\title{
A Conceptual Study on Performance of Small- Scale Industries in India
}

\author{
Shashank B. S. ${ }^{1 *}$ \& Sureshramana Mayya ${ }^{2}$ \\ $1 *$ Research Scholar, College Commerce and Management, Srinivas University, Mangalore- \\ 575001, Karnataka. \\ Orcid ID: 0000-0002-9302-2190, E-Mail: shashankbs73@gmail.com. \\ ${ }^{2}$ Research Professor, College Commerce and Management, Srinivas University, Mangalore- \\ 575001, Karnataka. \\ Orcid ID: 0000-0003-1951-0126, E-Mail: sureshmayya@ hotmail.com
}

Area of the Paper: Management

Type of the Paper: Research Case Study

Type of Review: Peer Reviewed as per $|\mathrm{C}| \mathrm{O}|\mathrm{P}| \mathrm{E} \mid$ guidance.

Indexed In: OpenAIRE.

DOI: https://doi.org/10.5281/zenodo.5782746

Google Scholar Citation: IJCSBE

\section{How to Cite this Paper:}

Shashank, B. S., \& Sureshramana Mayya, (2021). A Conceptual Study on Performance of Small-Scale Industries in India. International Journal of Case Studies in Business, IT, and Education (IJCSBE), 5(2), 342-353. DOI: https://doi.org/10.5281/zenodo.5782746

International Journal of Case Studies in Business, IT and Education (IJCSBE)

A Refereed International Journal of Srinivas University, India.

Crossref DOI : https://doi.org/10.47992/IJCSBE.2581.6942.0139

(c) With Authors.

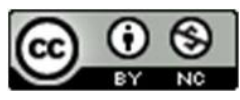

This work is licensed under a Creative Commons Attribution Non-Commercial 4.0 International License subject to proper citation to the publication source of the work.

Disclaimer: The scholarly papers as reviewed and published by the Srinivas Publications (S.P.), India are the views and opinions of their respective authors and are not the views or opinions of the S.P. The S.P. disclaims of any harm or loss caused due to the published content to any party. 


\title{
A Conceptual Study on Performance of Small-Scale Industries in India
}

\author{
Shashank B. S. ${ }^{1 *}$ and Sureshramana Mayya ${ }^{2}$ \\ $1 *$ Research Scholar, College Commerce and Management, Srinivas University, Mangalore- \\ 575001, Karnataka. \\ Orcid ID: 0000-0002-9302-2190, E-Mail: shashankbs73@ gmail.com. \\ ${ }^{2}$ Research Professor, College Commerce and Management, Srinivas University, Mangalore- \\ 575001, Karnataka. \\ Orcid ID: 0000-0003-1951-0126, E-Mail: sureshmayya@ hotmail.com
}

\begin{abstract}
Purpose: Small-Scale Industries (SSI) are critical to economic development, particularly in developing countries. SSI provide nearly forty percent of the gross industrial value added to the Indian economy. It is interesting to know the performance and status of small-scale industries by using data from the Ministry of Micro, Small, and Medium Enterprises (MSME) and analysing the SSI's strengths, weaknesses, threats, and opportunities.

Objective: This research aims to analyse the scheme introduced by the Government to improve the SSI output.

Methodology: For the study, we considered various articles, websites and tabular presentations.

Result: According to the study, government schemes and policies contribute to promoting SSI growth in India. SSI provides a more significant contribution to the country's export, and it creates more employment opportunities for youth.

Originality/value: The study determined the efficiency of small-scale industries in terms of unit establishment, production, job creation and export and also learned about some special government facilities provided through various schemes and programmes to address issues or problems and promote SSI's growth and development.
\end{abstract}

Paper type: Research Case Study.

Keywords: Problems of SSI in India, SWOT analysis of SSI, Job creation by SSI, SSI growth and development.

\section{INTRODUCTION :}

In India's economy, small and medium businesses play a critical role. It contributes significantly to the country's economy in terms of output, exports, and employment. According to the World Trade Organization (WTO), small-scale industries contribute 40 per cent of total industrial value-added and 50 per cent of total overall manufacturing exports, helping to prompt calls for increased investment in the sector [1]. The Indian Government has launched many initiatives aimed at promoting small businesses. According to the fourth census of Small and Medium Enterprises (SMEs) conducted by the Government of India, there are 15.64 lakh registered and operational SMEs throughout India, in that 15.64 lakh registered SMEs, 10.49 lakh (67.01 per cent) are manufacturing enterprises and 2.62 lakh (16.78 per cent) service industries, and 2.52 lakh (16.13 per cent) repairing and maintenance industries [2]. Microbusinesses cover various activities, including industrial production, maintenance and repair, raising capital, retail outlets, renovation, and infrastructural facilities. The Government is also trying to encourage small and medium-sized enterprises. The Indian economy is based on small-scale and cottage industries. The Government has taken several steps to encourage the growth of these industries. Small enterprises are small family-run businesses that family members run. Only in SSI hired labour involved in the production process. Both kinds of industry are generally agriculturally based and run their business operation in rural areas. The economic reconstructions of India depend on the balanced growth of the economy in the field of agriculture and industry. Small-scale industries have been encouraged by the Indian Government as alternatives to agriculture and heavy industries. Approximately 94 per cent 
of total SMEs are micro-enterprises, i.e., Industries with investment opportunities of less than Rs 25 lakh. Around 2443 clusters cover 321 products in the SMEs sector. There are many industries in the unregistered sector, with an estimated 91.64 lakh units operating in this sector. SSI in India, which formerly functioned in a protected environment, confronts new challenges in the globalised world. The liberalisation increased competition, unrestricted product circulation, investment, and strategic alliances for product development, production, sourcing, and marketing. As a result, small scale industries occupy a unique position in the industrial system in a growing nation like India. Because of the vast potential of small-scale industries, the Government of India has prioritised the SSI sector in its economic strategy for economic and ideological reasons.

\section{LITERATURE REVIEW :}

In this paper, Khan (2020) [3] examined factors of small-scale industry development and studied smallscale industries' policy. Small scales industries policy was announced in 1991, and this policy's primary intention is to maximise the total investment to Rs. 5.00.000. As per the study, this policy has a separate proposal to promote the tiny enterprise. Small scale industry providing the job opportunity and development of rural area/market. According to this survey, most rural people are involved in various types of handicraft work, which is a component of SSI. The paper also studied the problem faced by SSI and all the Central and State Government's measures to uplift the SSI. The author also identifies the performance of SSI in India from the year 1975 to 2011 relating to the production and export of the goods. This article gives precise information about the SSI problems and performance, how SSI is helping to create employment opportunities.

Based on the studies of Anshu Taunk, (2013) [4], we can get precise information about SSI; the author analyses the problem of SSI and the total outcome of SSI to national income. SSI is growing at a phenomenal rate labour problem is the major problem of SSI. The study also disclosed the performance of SSI from 1995 to 2010. Based on that analysis, we can know about changes that happen in the SSI unit. The study indicated that the annual growth and return on investment. It was apparent from the study that the removal of import restrictions also affected SSI negatively. The more significant challenge of SSI was how it would undergo a global transformation. It cannot thrive in the face of high tariffs and non-tariff barriers such as import licencing.

The study of Kumar Arya, A. and Kumar Jain, S. (2014), [5] showed that many small-scale enterprises have emerged in India, and fierce competitiveness has made the survival of small-scale industry challenging. Many SSIs are facing many problems like shortage of material, non-availability of skilled labourers etc. The paper focuses on Kaizen implementation at their units. The purpose of the research is to encourage practitioners to adopt Kaizen in India's small-scale companies. The approach used to execute Kaizen in small-scale industries in India. To show cause this, fishbone diagrams have been utilised. Savings in both money and time have been demonstrated as a consequence. Kaizen implementation helped recover 80 square feet of the working area and decreased processing time by 44.4 per cent and Rs. 64,000 was saved. Workflow improvements have been realised.

The above studies touched on various aspects like factors responsible for the development of small scale industry, the policy of favouring the development, the problem of small scale industry, the annual growth and return on investment, the various problems like shortage of raw material, non-availability of skilled labours and Kaize implementation. However, factors like resource underutilization, the implications of government and non-government programmes are not studied. Hence, an effort was made to study those problems.

Based on the study of Mubarak and Budanur Suresh (2021) [6], SSI playing the crucial role in providing the Job opportunity to public and to increase the national income. The study also suggests that India's focus and support for SBEs may be traced back to Mahatma Gandhiji's specific concern for handcraft and village-based businesses. Small business enterprises (SBEs) serve as accessory units to big enterprises, and this sector contributes significantly to the socioeconomic environment of the country's development The SBE sector has evolved as a dynamic, lively sector of the economy, and it holds the key to economic development in an economy like India. In fact, it accounts for approximately $40 \%$ of the country's industrial production, $42 \%$ of exports, and $65 \%$ of career opportunities and out of 50 crore SBEs in India where 4.6 lakh SBEs are in Karnataka state. Authors also provide information about Goods and services tax impact on small and medium enterprises. 
Due to a massive lack of funds, it is extremely difficult for SSI units to adapt to changing client needs as a result of globalisation. Considering the increasing in the number of SSI units and contribution by SSI units in production, employment generation, exports, etc. In this study we can clearly identify about SSI unit is helping to Improve the GDP and also SSI have the problem with related to finance (fund), Raw materials.

\section{OBJECTIVE OF STUDY :}

(1) To study the employment and investment opportunity provided by Small Scale Industries.

(2) To study the major problems faced by small scale industries.

(3) To know the strength, weakness, opportunity and threats of SSI's.

\section{RESEARCH METHODOLOGY :}

Data was collected from secondary sources like articles, newspapers, websites and performance reports of SSI in India.

\section{SMALL SCALE SECTOR :}

The concept "small scale industry" is not new to the Indian economy because it refers to age-old traditions and systems from the ancient period. The small-scale sector has been broadened to include small-scale enterprises, small-scale industries and all service-sector businesses that provide various services to the manufacturing industries. The Reserve Bank of India (RBI) currently defines small scale units as "Tiny Scale Industry" and includes those undertakings engaged in producing, refining, and warehousing commodities or goods in which capital investment in plants and industrial equipment is not made more than Rs. 5 crores.

The investments in plants and machinery for small businesses should not exceed Rs.25 lakh. SSI includes decentralised and informal sectors such as handloom and handicrafts. Small scale industries in India include the service/business enterprise industry, food and agro-based industries, and software industries. The Government encourages the growth of SSI to provide job possibilities, mobilise resources and capital for the equal distribution of national income, and boost industrialisation [6]. Based on the level of investment in plant and machinery, Micro, Small, and Medium Enterprises (MSMEs) have been categorised as tiny, micro, and large firms, as shown below.

Table 1: Manufacturing enterprises - the amount of investment in machines and equipment

\begin{tabular}{|l|l|}
\hline Description & Amount \\
\hline Microbusiness & Up to 25 lakh rupees \\
\hline Small business & More than Rs 25 lakh but less than Rs 5 crore \\
\hline Medium business & More than Rs 5 crores to Rs 10 crores \\
\hline
\end{tabular}

Source: [6]

Based on the amount of capital invested in equipment, MSMEs in the service sector have been categorised as micro, small, and medium industries, as follows

Table 2: Service sector - the amount of capital invested in equipment

\begin{tabular}{|l|l|}
\hline Description & Amount \\
\hline Microbusiness & Up to Rs.10 lakhs \\
\hline Small business & More than Rs10 lakh but not more than Rs 2 crores \\
\hline Medium business & More than Rs.2 crore but not more than Rs 5 crores \\
\hline
\end{tabular}

Source: [6]

\section{IMPORTANCE OF SMALL-SCALE INDUSTRY IN INDIA :}

The tiny sector (SSI) in India is privileged because of its accomplishments in the country's socioeconomic growth. Their contributions are highlighted in the following points.

- Ninety-five per cent of SSI units are located in India; small-scale industries that contribute to our country's balanced regional development are remarkable. 
- Small-scale enterprises, after agriculture, are the second-largest employers of human resources. They generate a more significant number of job opportunities per unit of capital invested than large industries.

- Small scale businesses provide a wide range of products, including mass-market goods, readyto-wear clothing, hosiery, stationery, soaps and detergents, home utensils, leather, plastic, and rubber products and processed meals and vegetables.

- Small businesses make simple goods with rudimentary technologies and rely on locally sourced materials. Material and labour are available all around the country.

- Small scale industry provides more opportunities for entrepreneurship. There will be no formalities to start a small scale industry. The initiatives are taken by the Government's policy stimulate and promote the development of agro-based rural industries [7].

Indian Micro, Small and Medium Enterprises have been contributing to entrepreneurial development and business innovations. According to Central Statistics Office, the contribution of the MSME sector in the India Gross Value Added (GVA) and Gross Domestic Product (GDP) from 2014-15 to 2018-19 is given below:

Table 3: Share of Gross Value Added (GVA) of MSME in all India GDP

\begin{tabular}{|l|l|l|l|l|l|r|}
\hline Figures in Rs. Crores adjusted for FISIM at current prices \\
\hline Year & $\begin{array}{l}\text { Total } \\
\text { MSME } \\
\text { GVA }\end{array}$ & $\begin{array}{l}\text { Growth } \\
(\%)\end{array}$ & $\begin{array}{l}\text { Total } \\
\text { GVA }\end{array}$ & $\begin{array}{l}\text { Share of } \\
\text { MSME in } \\
\text { GVA (\%) }\end{array}$ & $\begin{array}{l}\text { All India } \\
\text { GDP }\end{array}$ & $\begin{array}{l}\text { Share of MSME } \\
\text { in All India } \\
\text { GDP \% }\end{array}$ \\
\hline $2014-15$ & 3658196 & - & 11504279 & 31.80 & 12467959 & 29.34 \\
\hline $2015-16$ & 4059660 & 10.97 & 12574499 & 32.28 & 13771874 & 29.48 \\
\hline $2016-17$ & 4502129 & 10.90 & 13965200 & 32.24 & 15391669 & 29.25 \\
\hline $2017-18$ & 5086493 & 12.98 & 15513122 & 32.79 & 17098304 & 29.75 \\
\hline $2018-19$ & 5741765 & 12.88 & 17139962 & 33.50 & 18971237 & 30.27 \\
\hline Source: [8]
\end{tabular}

According to the fourth, All India survey of SSI, the small-scale industry contributes to the country's number of businesses, jobs, and output. SSI's performance is based on data from the 4th All India Census, augmented with data from the EC, 2005, and growth rates recorded during the fourth (1998) and fifth (2005) economic censuses.

The number of Micro, Small and Medium Enterprises has been increasing in India; the data pertaining to the year 2015-2016 to 2019-2020 has been given in table 4:

Table 4: Number of Micro, Small and Medium Enterprises (MSMEs) in India (2015-2016 to 2019-2020)

\begin{tabular}{|l|r|r|r|r|}
\hline Year & Micro & Small & Medium & Total \\
\hline $2015-2016$ & 421006 & 70926 & 2645 & 494577 \\
\hline $2016-2017$ & 2147491 & 216751 & 8619 & 2372861 \\
\hline $2017-2018$ & 1344234 & 166480 & 6619 & 1517333 \\
\hline $2018-2019$ & 1870282 & 241343 & 9403 & 2121028 \\
\hline $2019-2020$ & 2206885 & 295367 & 10981 & 2513233 \\
\hline
\end{tabular}


International Journal of Case Studies in Business, IT, and Education

Table 5: SSI's Employment and investment Performance

\begin{tabular}{|l|r|r|r|r|r|}
\hline Year & $\begin{array}{l}\text { No. of total } \\
\text { SSI (In lakh) }\end{array}$ & $\begin{array}{l}\text { Fixed } \\
\text { Investment } \\
\text { (In crores) }\end{array}$ & $\begin{array}{l}\text { Employment } \\
\text { (in lakh } \\
\text { person) }\end{array}$ & $\begin{array}{l}\text { Average } \\
\text { Investment }\end{array}$ & $\begin{array}{l}\text { Average } \\
\text { Investment }\end{array}$ \\
\hline $2000-01$ & 101.1 & 27279 & 238.73 & 2.70 & 2.36 \\
\hline $2001-02$ & 105.21 & 154389 & 249.32 & 1467.44 & 2.37 \\
\hline $2002-03$ & 109.49 & 162317 & 260.21 & 1482.48 & 2.38 \\
\hline $2003-04$ & 113.95 & 170219 & 271.42 & 1493.80 & 2.38 \\
\hline $2004-05$ & 118.59 & 178699 & 282.57 & 1506.86 & 2.38 \\
\hline $2005-06$ & 123.42 & 188113 & 294.91 & 1524.17 & 2.39 \\
\hline $2006-07$ & 261.01 & 500758 & 805.23 & 1918.54 & 3.09 \\
\hline $2007-08$ & 272.79 & 558190 & 626.34 & 2046.23 & 2.30 \\
\hline $2008-09$ & 285.16 & 621753 & 659.35 & 2180.37 & 2.31 \\
\hline $2009-10$ & 298.1 & 693835 & 695.38 & 2327.52 & 2.33 \\
\hline $2010-11$ & 428.73 & 1105934 & 965.15 & 2579.56 & 2.25 \\
\hline $2011-12$ & 447.64 & 1182757 & 1011.69 & 2642.21 & 2.26 \\
\hline $2012-13$ & 467.54 & 1268763 & 1061.4 & 2713.70 & 2.27 \\
\hline $2013-14$ & 488.46 & 1363700 & 1142.29 & 2791.84 & 2.34 \\
\hline $2014-15$ & 510.57 & 1471912 & 1171.32 & 2882.88 & 2.29 \\
\hline
\end{tabular}

The small-scale industry (SME) sector remains a significant contributor to GDP, industrial production, job creation, and exports. According to the final results, the number of MSME grew from the third to the fourth All-India census of SMEs. 101.1 lakh units in 2000-2001 to 298.1 lakh units in 2009-2010 and can be increased to 510.57 lakh units in 2014-2015.

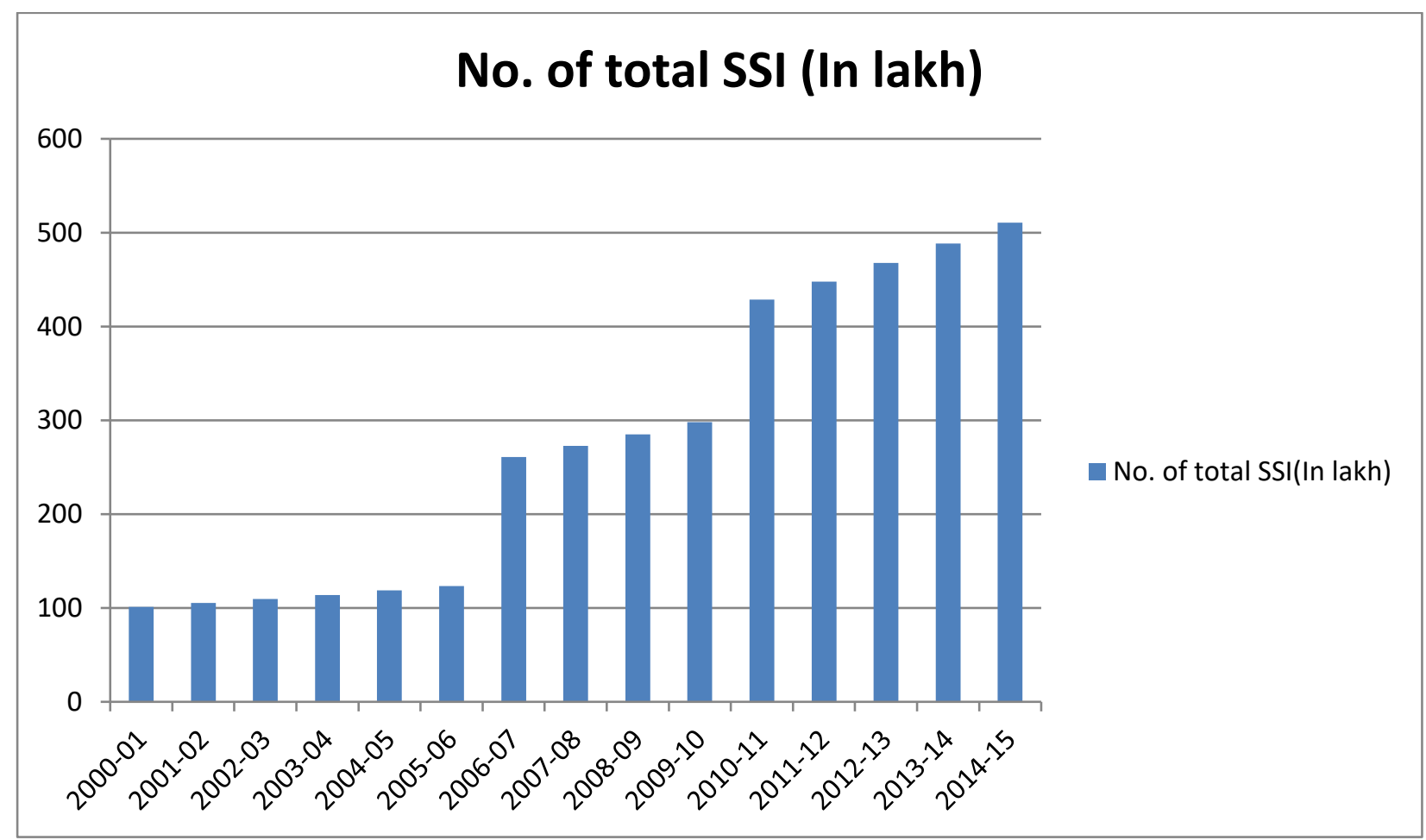

Fig. 1: Growth of small-scale industry during the period from 2000-2001 to 2014-2015

From the above figure 1, it is apparent that the number of SSI has been growing from 2000 to 2015 . From the diagram, we can clearly understand the SSI unit is increasing. 


\section{Fixed Investment(In crores)}

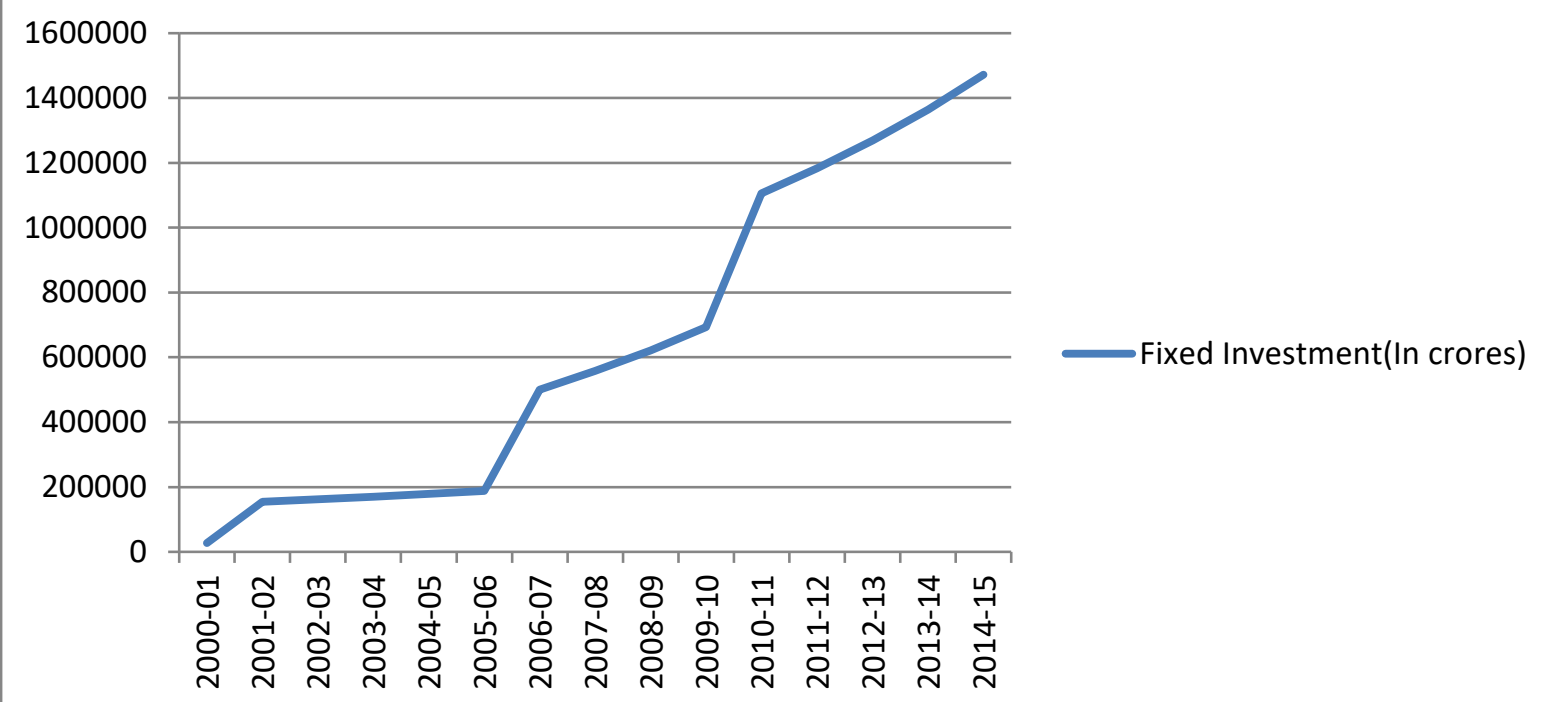

Fig.2: Fixed Investment of Small-scale industry during the period from 2000-2001 to 2014-2015

Above the figure 2 indicate the total investment of SSI from 2000 to 2015. The investment has increased from 2000 to 2015 .

\section{Employment (in lakh person)}

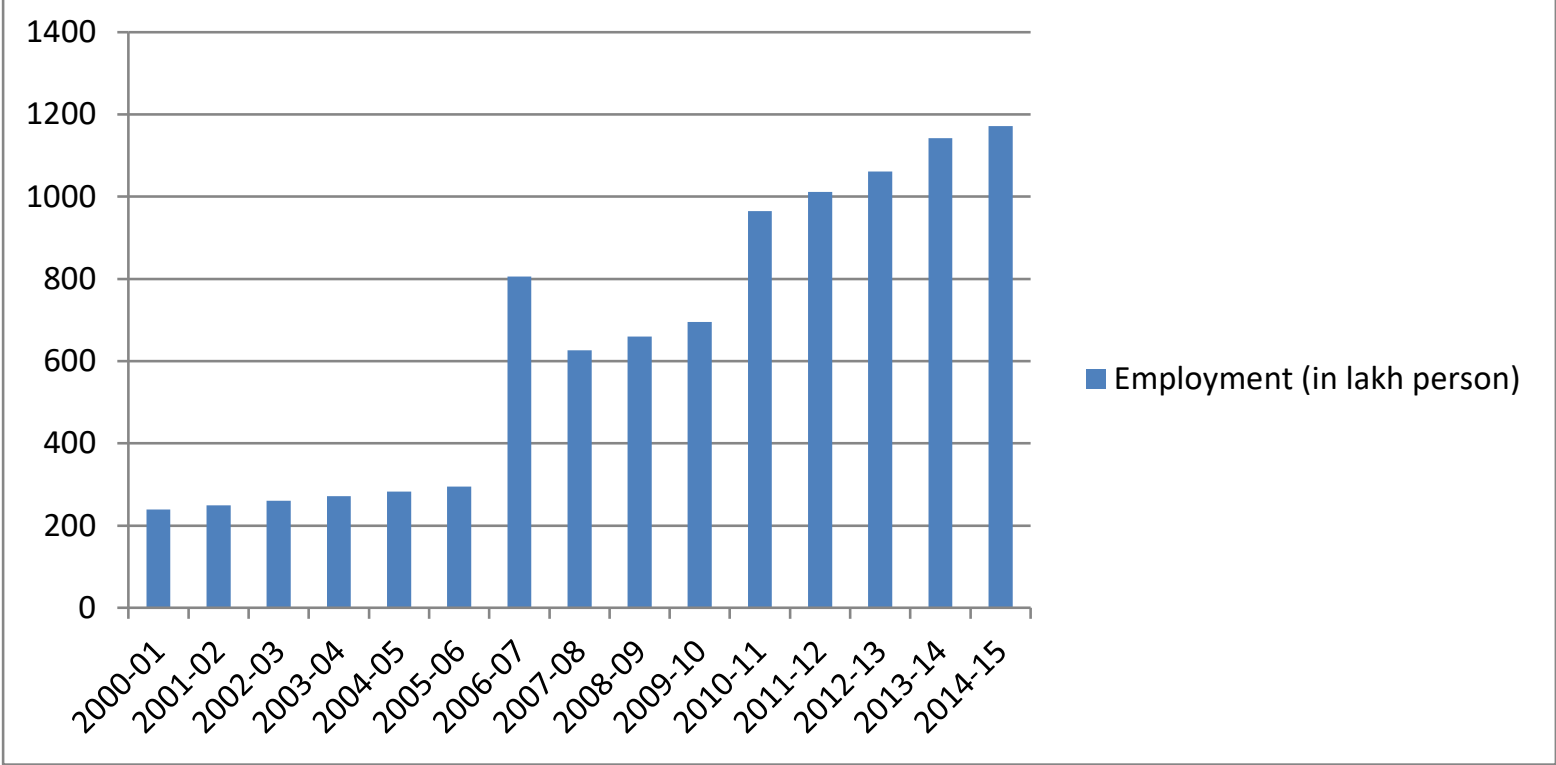

Fig.3: Total Employment opportunity by small scale industry during the period from 2000-2001 to 2014-2015

The above diagram (figure 3) shows the Employment opportunity by SSI; we can clearly understand that SSI help to create more employment opportunities.

\section{PROBLEMS FACED BY SSI :}

Small scale industry is growing day by day in India, but some of the SSIs do not receive the necessary funding or assistance from the relevant authorities like banks, financial institutions, and financial corporations. It creates constraints to small scale units to compete at the national and international levels. India's small-scale industry has been unable to progress satisfactorily due to various issues that they face when running businesses. Despite its immense promise, SSI is plagued by the challenges described below: 


\subsection{The Skilled manpower shortage:}

A small business's success is determined by the entrepreneur and his or her employees, who must be skilled and efficient. Small enterprises face several obstacles due to human factors and unskilled labour. Small-scale industries face challenges due to a lack of skilled labour in the rural sector [8].

\subsection{Inadequate credit system:}

SSIs have been facing issues like an inadequate and timely supply of credit facilities. A significant issue confronting small scale industries is due to a lack of money and, in part, due to the small units' poor creditworthiness, a lack of finance is the most significant impediment to the development of small-scale industries. Small businesses' financial difficulties are a symptom of the more significant issue. This is partly due to the nature of a small business organisation, which contributes to capital scarcity in the economy as a whole.

\subsection{The difficulty of raw materials:}

Whether they use locally accessible raw materials or imported raw materials, small units confront considerable problems in getting raw materials. The problems develop as a result of faulty and irregular raw material deliveries. A shortage of sufficient raw materials, occasionally low-quality raw materials, rising raw material costs, a foreign exchange crisis, and, most crucially, entrepreneurs' lack of awareness about government policies are all obstacles for small-scale businesses.

\subsection{Spread of quantitative restrictions ( $Q R s)$ :}

India maintains some quantitative restrictions on various agricultural, textile, and other goods. Article XVIII-B of the general provisions covers industrial products. Agreement on tariffs and trade India has issued a WTO for a specific period of seven years when these import restrictions are to be implemented may be removed.

\subsection{Industrial tariffs:}

While bottlenecks have impeded some Indian SSIs due to a lack of access to economies of scale, others have been granted protection. India has eliminated quantitative restrictions imposed. India has pledged to maintain a tariff cap. A $40 \%$ binding on finished items and a $20 \%$ binding on raw materials intermediate products, such as machinery and equipment, fall under this category.

\section{FOLLOWING ARE THE SEHEME INTRODUCED BY GOVERNMENT TO IMPROVE THE SSI :}

8.1 Credit guarantee scheme for micro and small industries:

This scheme aims to assist first-generation entrepreneurs in pursuing credit guarantee support for collateral-free/third-party guarantee-free loans to micro and small businesses, especially where the collateral is not available, creating self-employment prospects. This scheme is a collateral/third-party guarantee free credit facility (both fund and non-fund based) offered by qualifying institutions to new and existing small enterprises, including service enterprises, with a credit limit of Rs.2 crores [9].

\subsection{MUDRA Units:}

The scheme also addresses the entrepreneurs need to introduce new technology/automation to modernise the existing unit. The scheme's principal goal is to boost the existing industry's growth. MUDRA is providing up to Rs.10 Lakh loan [10].

\subsection{Procurement and marketing supporting scheme:}

Promoting new market access initiatives, raising awareness, and educating MSMEs on various marketing-related tactics are all goals. Efforts are made to conduct trade shows, internet advertising, emarketing based on government procurement policies to boost the sale [10].

\subsection{The small business development centre in rural areas:}


NABARD introduces this scheme. It works to help individuals and groups who are socially and economically disadvantaged. Its programmes employ a huge number of unemployed rural youth and women in various trades, including food preparation [11].

\section{SWOT ANALYSIS OF SMALL-SCALE INDUSTRY IN INDIA :}

Industry needs sufficient infrastructural facilities in order to function properly. However, the majority of SSIs operate with insufficient infrastructure. The government's cluster development program's goal is to establish Common Facility Centers to obtain advanced tools, technology, design. In the SSI units, highly trained human resources are a critical element of successful. Attracting and retaining present human resources, as well as developing fresh skills, is crucial. To address this problem, the government has launched a number of capacity-building initiatives. Programs for entrepreneurship development and vocational training. The strength, weakness, opportunities, and threat (SWOT) analysis [12-13] in terms of SSIs.

\section{Strength:}

- Adapting to change is critical in business, especially for small businesses, because they are not bound by bureaucratic inertia and can usually respond to the marketplace more quickly [14].

- Outstanding customer service - small business owners have a closer relationship with their clients and customers, resulting in increased accountability and maturity. They usually take a more personal approach to client interaction. Customers who are treated as if they are family are more inclined to return to a business.

- Self-reliance is another benefit of the SSI. The owners have complete control over their company. As a result, as a reward for small business owners, there will be the freedom to operate independently.

- It is a well-known fact that bureaucratic firms have a more challenging time innovating and creating new products and services. Whether it is in response to changes in fashion, demographics, or competitor advertising, a small business can usually make quick decisions in days.

- Small scale industry helps to give a quick return on investment. It is usually from 2 to 5 years.

\section{Weaknesses:}

- Reaching enough potential customers to build a thriving customer base can be difficult. Small businesses that do not provide a high-quality product or service may make potential customers less likely to do business with SSI [15].

- One of the most significant challenges for small business owners is raising capital because institutional lenders such as banks and government-owned financial institutions invest their own money for big business. Banks are reluctant to provide money to small businesses [16].

- Small business owners must bear high production costs, which is a weakness for small enterprises.

- The small-scale industry faces a problem of lack of skilled employees.

- Most small enterprises do not take advantage of information technology and its applications, such as creating a prototype machine for a product, total quality management, automation, etc., due to lack of resources [17].

\section{Opportunities:}

- SSI benefited from government support, product reservation, excise relief, and ancillary for large businesses in the current scenario business.

- $\quad$ SSI has access to opportunities because several bilateral and multilateral trade agreements have been signed, which help a significant revenue source for entrepreneurs/business owners [18].

- Credit assistance with more and more government initiatives for their promotion is offered; entrepreneurs/business owners can expect some relief in terms of credit facility access. 
- $\quad$ The National Small Industries Corporation (NSIC) has launched several marketing campaigns to promote SSI. As a result, small business owners can take advantage of adequate marketing assistance available from government agencies to help SSI [19].

\section{Threats:}

- The threats identified in this study are lack of financial prudence, competition from large and multinational corporations [20].

- SSIs also facing technological obsolescence, negligence toward industrial training, and increased input costs.

- Recently, increased costs such as salary, land, raw materials, and exchange rates, combined with cash flow challenges resulting from recovering account receivables, have all conspired to make SSI's business environment extremely difficult.

\section{FINDINGS :}

- SSIs help to create more and more employment opportunities.

- SSI units provide medical facilities and safety uniforms to their workers at the workplace. They also provide other facilities such as subsidised food, transport facilities, education etc.

- Due to the competition from large scale industries, SSI faces problems related to marketing, labour, etc.

- The study observed a growth in the number of SSI units, and SSI units also contribute to production, employment generation, promotion of exports.

- It indicates that globalisation has harmed the SSI units. It clearly shows that SSI units were not at all prepared to face the challenges of globalisation [20].

\section{SUGGESTIONS :}

- The bank should grant short, medium and long term loans at a low-interest rate to SSI.

- The SSI units must provide appropriate training to their managers from the professionals to improve their managerial abilities.

- The SSI was founded in response to the necessity to address the globalisation era's difficulties. Infrastructure must be built to a high standard by units. SSI unit should always strive to achieve the goal of customer satisfaction.

- Special efforts should be made to educate employees about the vision, goals, and objectives. The mission of the SSI units and inter-departmental policies and procedures are likely strategies for achieving the desired output and results.

- It is always preferable to assign jobs and responsibilities based on merit. They have to consider the individual's experience and follow the "right person-right job" concept in human resources management.

\section{CONCLUSION :}

Small-scale industries are critical to the country's growth. It accounts for about $40 \%$ of the gross industrial value added to the Indian economy. Small-scale industries are being explored across the country, and they are meeting local demand [21]. As a result, SSIs play an essential role in regional development. The Indian Government announced some policies and programmes to assist SSIs and started various initiatives that have been done to enhance credit flow to rural areas and improve the quality of life for the workers working in the SSIs. The Government has also implemented various schemes and incentives to promote institutional infrastructure for SSIs [22]. Government supports globalisation and liberalisation. It is anticipated that subsidies will likely rise, boosting SSIs for export competitiveness. SSIs in India are progressively focused on enhanced production methods, penetrative marketing strategies, and management competencies to sustain and strengthen their operations. The dynamism, flexibility, and innovative drive are also required to be developed. The promotors of SSIs must be educated and informed about the latest global developments and assist in acquiring the skills required to keep up with the global pace developments [23]. SSIs have been extremely beneficial in terms of revenue generation, primarily through the export of goods and addressing issues such as employment while improving people's socio-economic conditions. 


\section{REFERENCES :}

[1] Singh, J., \& Singh, D. (2014). Problems related to the Financing of Small Firms in India. International journal of innovative research and development, 3(1), 317-321.

Google Scholar X

[2] Agarwal Varsha, A. U. (2019). A Study on Challenges Faced by SMEs in India. International journal of engineering research and management (IJERM), 06(09), 33-38.

Google Scholar X

[3] Khan, W. (2020). Understanding The Dynamics of Small-Scale Industry: A Case Study of Indian Context. Journal of critical reviews, 7(7), 1018-1023.

Google Scholar $x^{\top}$

[4] Anshu Taunk, A. K. (2013). Fear and Challenges Faced by Small Scale Industries of India in the World of Globalization. Global journal of human social science interdisciplinary, 13(3), 43-48.

Google Scholar X'

[5] Kumar Arya, A. and Kumar Jain, S. (2014), Impacts of Kaizen in a small-scale industry of India: a case study. International journal of lean six sigma, 5(1), 22-44.

Google Scholar X

[6] Mubarak and Budanur Suresh (2021), Impact of Goods and Services Tax on Small Scale Industries In India. International Journal of Research and Analytical Reviews (IJRAR), 8(1), 251-258. Google Scholar $X$

[7] Monika, G. (2017). A Study on Small Scale Industries and Their Impact in India. International Conference on emerging trends in engineering, science and management, 32(1), 1405-1415. Google Scholar X

[8] Raj, K., \& Aithal, P. S. (2020). A New Concept of Circular Model of Management for Achieving Sustainable Success and Growth. International journal of management, technology, and social sciences (IJMTS), 5(1), 1-17.

Google Scholar $\chi^{7}$

[9] Central Statistics Office (CSO), Ministry of Statistics and Programme Implementation. http://mospi.nic.in/central-statistics-office-cso-1 Accessed on November, 14,2021

[10]. Devi Kalyani.S, S. (2017). Growth and Performance of Medium and Small Scale Industry in India. International journal of industrial economics and management, 16(4), 189-196.

Google Scholar $X^{\top}$

[11] Mukherjee, S. (2018). Challenges to Indian micro small scale and medium enterprises in the era of globalisation. Journal of global entrepreneurship research, 8(1), 1-19.

Google Scholar $\chi^{7}$

[12] Aithal, P. S., \& Kumar, P. M. (2015). Applying SWOC analysis to an institution of higher education. International Journal of Management, IT and Engineering, 5(7), 231-247.

Google Scholar X

[13] Aithal, P. S. (2017). Industry Analysis-The First Step in Business Management Scholarly Research. International Journal of Case Studies in Business, IT and Education (IJCSBE), 1(1), 113.

Google Scholar 7

[14] Frese, M., Van Gelderen, M., \& Ombach, M. (2000). How to plan as a small scale business owner: Psychological process characteristics of action strategies and success. Journal of small business management, 38(2), 1-17.

Google Scholar $\chi^{7}$

[15] Banik, S. (2018). Small Scale Industries In India: Opportunities And Challenges. International journal of creative research thoughts (IJCRT), 6(1), 337-341. Google Scholar ${ }^{\top}$ 
[16] Singh, R. K., Garg, S. K., \& Deshmukh, S. G. (2010). Strategy development by small scale industries in India. Industrial Management \& Data Systems.

Google Scholar ${ }^{\nearrow}$

[17] Subrahmanya, M. B. (2005). Small-scale industries in India in the globalisation era: performance and prospects. International journal of management and enterprise development, 2(1), 122-139.

Google Scholar ${ }^{\top}$

[18] Desai, D. A. (2006). Improving customer delivery commitments, the Six Sigma Way: a case study of an Indian small scale industry. International journal of six sigma and competitive advantage, 2(1), 23-47.

Google Scholar $x^{7}$

[19] Zeinalnezhad, M., Mukhtar, M., \& Sahran, S. (2014). An investigation of lead benchmarking implementation: a comparison of small/medium enterprises and large companies. Benchmarking: An International Journal. 5(1), 405-418.

Google Scholar X

[20] Suresh, P., \& Mohideen, M. A. (2012). Small-medium enterprises in India-Issues and prospects. International journal of management research and reviews, 2(2), 247.

Google Scholar $\chi^{\top}$

[21] Kumar, M., Antony, J., Singh, R. K., Tiwari, M. K., \& Perry, D. (2006). Implementing the Lean Sigma framework in an Indian SME: a case study. Production planning and control, 17(4), 407423.

Google Scholar $X^{\top}$

[22] Pillania, R. K. (2008). Strategic issues in knowledge management in small and medium enterprises. Knowledge management research \& practice, 6(4), 334-338.

Google Scholar $X^{\top}$

[23] Hajela, A., \& Akbar, M. (2013). Internationalisation of small and medium software firms from India. International journal of technological learning, innovation and development 2, 6(1-2), 88101.

Google Scholar X

$* * * * * * * * * *$ 